\title{
Supporting the next generation
}

\author{
Tom Moberly editor
}

BMJ Careers

Last week the government and the BMA stepped back from the brink in the escalating dispute over the new contract for junior doctors in England (doi:10.1136/bmj.i2635). The five day "pause" for further negotiations offers a last ditch opportunity to tackle outstanding areas of disagreement (doi:10.1136/bmj. i2572), and junior doctors will have the chance to vote on any proposals (doi:10.1136/bmj.i2663).

Before the pause, the government maintained that there was only one substantive area of disagreement: antisocial hours (http://bit.ly/1NqrNWu). The BMA argued that there were at least seven, including safeguards and protection against working excessive hours (http://bit.ly/1TQnEKz). At the time of writing, it seems clear that both sides will need to make major compromises if they are to close the gap. But even an agreement on these outstanding issues is unlikely to diminish junior doctors' anger or their animosity towards Jeremy Hunt.

Firstly, because reaching a compromise on these areas would not deal with a key criticism of the new contract: that it is "not safe" (http://bit.ly/1X15SC5). The junior doctors argue that, although it is designed to support seven day service provision, the contract is not linked to plans to establish adequate staffing levels, especially those needed to provide a seven day service
(http://bit.ly/1Y1FbLU). In fact, as the Public Accounts Committee has said, there has so far been "no coherent attempt" by the government to assess the staffing implications of its proposal for seven day services (doi:10.1136/bmj.i2664).

Secondly, the anger that has fuelled the junior doctors' campaign has its roots in far wider issues (http://bit.ly/1TMyy43) that won't be resolved by any change to the contract. Despite restrictions on hours, junior doctors' work has become more demanding in recent decades, while changes to training, support frameworks, and team structures have eroded their job satisfaction and career expectations (http://bit.ly/1T4Ibfy). All these factors have contributed to what Neena Modi and David Oliver each describe as "plummeting morale" (blogs.bmj.com/ bmj).

The BMA and the government have acknowledged the need to confront these wider issues. The medical profession as a whole needs to consider what part it can play in reversing the decline in junior doctors' morale. That means improving medical leadership at a local and national level, and working together to find new and better ways to support the next generation of doctors. 